\title{
Is Print Readers Declining? A Survey of Indian Online Newspaper Readers Pradeep Tewari*
}

Senior Photo Journalist, The Tribune Publication, India

*Corresponding author: Dr. Pradeep Tewari, Ph.D. Senior Photo Journalist, The Tribune, Publication, Chandigarh, India, Tel: 91-9814033941; E-mail: drpradeeptewari@gmail.com

Rec date: June 20, 2016; Acc date: July 05, 2016; Pub date: July 10, 2016

Copyright: (c) 2016 Tewari P. This is an open-access article distributed under the terms of the Creative Commons Attribution License, which permits unrestricted use, distribution, and reproduction in any medium, provided the original author and source are credited

\begin{abstract}
An online study was conducted among 3,183 online newspaper readers of India. The study reveals that majority of the online news consumers (90 percent) were still reading printed newspapers. It was found that online newspapers have not much affected the print newspaper circulation. But print has start losing young readers. As per the study 18 percent of $15-20$ age group, 12 percent of 20-30 age group and 8 percent of $30-40$ age group readers have reduced their interest to read print newspapers, they prefer to read online newspapers. The displacement effect of online media is very low. The older generation above 50 years read both the media equally, while 3 percent readers of 40-50 age groups have reduced use of print newspaper. While gender wise young male (15-20) readers have reduced interest on print media more than women readers, 21 percent by male and 14 percent by women readers. Popup ads are the most irritating thing on the online newspapers.
\end{abstract}

Keywords: Online news consumer; Online newspaper; Internet news; Media displacement; e-reader

\section{Introduction}

Media research shows the decline in print newspaper readership in America and Europe. Media publication shifted to online editions because of a decline in advertising revenues [1].

Mass media was affected by new technologies much before the emergence of Internet technology, like TV and radio have changed the readership habits. Many researchers have investigated the effects of the new media of their time-for example, Lazarsfeld [2] studied radio and Belson [3] studied television, both concluding on a limited displacing effect.

Information and Communication Technologies have grown rapidly around the world and advance Internet technology have given mass media a new shape, growth of online media have been noticed in the last 10 years. According to the OECD, around 5\% of all internet visits are related to reading news online. Now the digital media has become the inherent part of modern society and become a challenge to the print media. Many people nowadays are accessing Internet for updated news in any place and at any time.

Internet is used for several purposes to get information, entertainment, official work, to connect with friends and relatives around the world and to do every day routine work. Online newspapers differ significantly from the print media: Online readers read from a digital format on computer screen or on smartphone, they and move around by clicking on links and menu buttons.

They navigate through a virtual space and may run into problems orienting themselves in the complex net structure [4]. Internet users throughout the world are now able to read the news within the minute of the happening. Advances in the mobile technologies, Internet technologies, and introduction of Smartphone's and wireless networks are the main factor to give boost to online media. Online media allow the reader to access the news constantly in real time.
The Chicago Tribune was the first newspaper, which started online newspaper after publishing its content in 1992. Whereas Palo Alto Weekly was the first regularly published online newspaper of the world, which started in January 1994, provided its full content free of cost [5]. In 1998 USA today has started paid access to its online archives; El País has also started charging for articles access in 2002. However, it was discarded due to the unwillingness of users to pay online reading.

The beginning of new communication technology (NCT) gave opportunities and challenges for conventional media [6]. People use Internet for two purposes, first it is used as mediated interpersonal technologies, which are for social bonding, relationship maintenance, problem solving, and persuasion. Second the Internet is used as mass communication, which is for informational and leisure purposes [7]. The previous studies proved that the use of Internet and computermediated communication is increasing [8-10].

Following the growth in the communication technology, news portals have played an important role as 24 hours news outlets. The growth of online newspapers between 2007-09 have resulted decline of print newspaper circulation $30 \%$ in the US, $25 \%$ in the UK, and slightly less in Greece, Italy and Canada [11]. Studies also demonstrated that main reason for the displacement of media is functional exchangeability [12-14].

Most of the traditional media television, radio, and newspapers start converting their news content digitally and started their websites. All the major newspapers of India have started their e-papers and online newspapers. As per Internet Live Stats, Internet users around the world are rapidly growing and 40 percent of the world population has an internet connection.

The latest research by the internet and mobile association of India (IAMAI) and IMRB international shows that the Internet usage in India has gone up by 32 percent from October 2013 to October 2014. As per the latest report of IAMAI, 402 million people will use Internet by December 2015; India will overtake the US Internet users. This research was conducted to examine the online reader's age group, who 
read print and online newspapers. This study will provide the overview of displacement of print media among various age group e-readers. It will help to improve the future of online journalism in India.

\section{Review of literature}

The presence of new media is a challenge to conventional media, especially the printed newspaper [15]. As per the research US newspaper industry is suffering through what could be its worst financial crisis since the great depression due to new media [16]. Print media seem to be losing young readers simply because they want news on demand, and to control and customize content, time and the medium itself. In India print media are flourishing [17].

Reading behaviour of online news readers differ from print media: Reading a newspaper is something they do with pleasure and sometime during breakfast, in a coffee break after lunch, on the train or in the subway. In contrast, reading an online newspaper is something you do in much shorter breaks, perhaps between two emails, usually in your office in the early morning, or during lunch. Online readers make brief visits to the news sites several times a day with the expectation of obtaining a quick overview over the latest events [18].

As per the study Westlund and Fardigh [19] online news has acquired a stronger position among users over time, gender has the strongest complementing effect, as men are distinguished users of both print and online news.

In some research, researchers discussed the newspaper and the online news site being complementing and displacing when they serve different needs. One research shows that youths feel, news sites serve the same needs as newspapers [20,21]. A study suggests that old patterns of news still prevail and that the best predictors of frequency and sophisticated use of the Internet are young age, high income, and high level of education [22].

In a recent study, "Is Print Really Dying? The State of Print Media Use in Europe" finds that print media is still an important media in the new communications environment among European audiences [23].

This research attempts to investigate the online newspapers popularity, frequency of the Internet usage for online news and what kind of news readers prefer. The gap is a considerable issue for the betterment of the online media. Why do online news readers are growing? This is the main purpose of this research project.

\section{Objective}

Keeping in view the above discussion, the broader objects of the study was to assess the displacement effect of online newspaper on the print media. The specific objectives of the study were as follows:

- How much online newspaper reader read print newspapers?

- Who reads more online newspapers?

- To find out the problems of online newspaper readers.

\section{Methodology}

The study was conducted on the Indian Internet users aged 15 and over. The online survey method was adopted to know the displacement effect of online newspapers in India. It is a most popular method to study the Internet users. It is a systematic gathering of data from the audience by sending e-mails to Internet users or posting questionnaire on social media and web pages. Respondents complete the questionnaire over the World Wide Web.

Recent developments in the field of communication technologies have given choice of survey methods. Now with the help of internet on can do survey through e-mail, Webbased tools and Social media. Online survey has faster responses and save the time Llieva, Baron, and Healey [24], researcher can get data from distant locations [25-28].

In recent years an increase of online surveys have noticed for online studies, presenting scholars with new challenges in terms of applying traditional survey research methods to the study of online behavior and Internet use [16,28-30].

Responses of online surveys can be easily checked on the smart phone. Data can be immediately checked by the researcher via email, or posted to an HTML document or database file. It helps researchers to conduct preliminary analyses on collected data while waiting for the desired number of responses to accumulate [24].

Online surveys are increasing in the last 10 years, conducting web or online surveys in comparison with other methods is low cost $[24,25,28]$. Web surveys have a number of advantages over other survey methods. They are convenient for respondents to take on their own time and save the time of a researcher as it is automatically stored electronically and analysis becomes easier.

For this study questionnaire was created on the Google Forms, a link of questionnaire posted on social media and mailed on various online news readers and provided links to the questionnaire on my own web page for six month July 1 to December 31, 2014. The questionnaires posed only close-ended questions.

Questionnaire was checked by the other expert's one senior journalist of The Tribune Publication and two teachers of Mass Communication for the validation and reliability of questionnaire. After that the survey questionnaire was sent to 50 respondents to measure the reliability of questionnaire through the test-retest reliability method. The score of test-retest reliability was $r \geq 0.78$.

The respondent for this survey were those who have the habit of reading news online and are of age groups between 15 and above. The data was collected by a questionnaire using web survey and findings and conclusions have been drawn based on the survey results.

\section{Data analysis}

As per the previous studies online news readers are growing rapidly. Questionnaires were distributed through the internet, using erecourses (e-mail, Facebook, Twitter, and blog) without knowing the gender of respondents. The Table 1 shows the displacement effect of online newspapers is very low in India. Only 10 percent of the respondents have stopped reading the traditional media (newspapers). While majority (90 percent) of online news consumers is using traditional media for the news, interestingly women respondents are reading both the medium higher (4 percent) than men respondent. 
Page 3 of 4

\begin{tabular}{|l|l|l|l|l|}
\hline Read print newspaper & $\begin{array}{l}\text { Respondent } \\
(\mathbf{n}=\mathbf{3 1 8 3})\end{array}$ & Percent of respondent & Percent of $\mathbf{m e n}(\mathbf{n}=\mathbf{2 0 6 4})$ & Percent of women $(\mathbf{n}=\mathbf{1 1 1 9})$ \\
\hline Yes & 2865 & 90 & 88 & 92 \\
\hline No & 318 & 10 & 12 & 8 \\
\hline
\end{tabular}

Table 1: Use of print newspaper and online newspaper by men and women.

As 88 percent male are reading news in print medium and online medium, whereas 92 percent women read news in both the medium.

\begin{tabular}{|l|l|l|l|l|l|l|}
\hline $\begin{array}{l}\text { Age } \\
\text { group }\end{array}$ & $\begin{array}{l}\mathbf{R} \\
(\mathbf{n = 3 1 8 3})\end{array}$ & Both R & $\begin{array}{l}\text { Male } \\
\mathbf{R}\end{array}$ & $\begin{array}{l}\text { Male Both } \\
\mathbf{R}\end{array}$ & $\begin{array}{l}\text { Wome } \\
\mathbf{n} \\
\mathbf{R}\end{array}$ & $\begin{array}{l}\text { Women } \\
\text { Both R }\end{array}$ \\
\hline $15-20$ & 694 & $571(82 \%)$ & 405 & $320(79 \%)$ & 289 & $251(86 \%)$ \\
\hline $20-30$ & 1329 & $1170(88 \%)$ & 832 & $720(87 \%)$ & 497 & $\begin{array}{l}450 \\
(90 \%)\end{array}$ \\
\hline $30-40$ & 564 & $519(92 \%)$ & 406 & $374(92 \%)$ & 158 & $145(91 \%)$ \\
\hline $40-50$ & 354 & $340(97 \%)$ & 235 & $227(96 \%)$ & 119 & $113(95 \%)$ \\
\hline $50-$-above & 242 & $242(100 \%)$ & 186 & $186(100 \%)$ & 56 & $\begin{array}{l}56 \\
(100 \%)\end{array}$ \\
\hline
\end{tabular}

Table 2: Age and gender wise online newspaper readers.

The Table 2 shows the younger age groups readers are much active in online news, as 82 percent respondent of 15-20 age group are reading online newspapers and print medium, 18 percent youth have reduced using print media. While 88 percent readers of $20-30$ age group reading both the media, followed by $30-40$ age group ( 92 percent), 40-50 age group (97 percent) and 50 above age group (100 percent) reading both the medium. Furthermore, although significantly more young women reported reading print newspapers more than young men. 86 percent women readers of 15-20 age group read both the media, while in this age group men readers are 79 percent.

\begin{tabular}{|c|c|}
\hline Response & Frequency $(\mathbf{n}=\mathbf{3 1 8 3})$ \\
\hline Slow internet speed & $37 \%$ \\
\hline Heavy content & $30 \%$ \\
\hline Lot of advertisements & $38 \%$ \\
\hline Popup advertisement & $70 \%$ \\
\hline
\end{tabular}

Table 3: Problems during reading the online newspapers.

\section{Discussion}

The study reveals that young people have reduce the usage of traditional media. As per the study younger 15-20 and 20-30 year age bracket readers read less print media, they read more online news. But young women news readers are using both the media more than male, 86 percent and 79 percent respectively. Whereas the displacement effect is very low ( 3 percent) among 40-50 age group readers and above 50 age all are reading both the media.

As per the survey, most of the (90 percent) online readers are also using traditional media along with digital media for the news. Online news readers are growing around the world, because readers can access all kind of media from the Internet. Earlier readers were totally dependent on a single daily newspaper, radio or TV channel. Now all the traditional media have started their online newspapers (e-papers) and updating their website regularly with latest news.

\section{Conclusion}

Internet users in India growing very fast in India, as per the latest report of Internet and Mobile Association of India, India will overtake the US (as the second largest base) it will touch 402 million users by December 2015. As per the research by US based research firm eMarketer (2014), India will overtake the US as the second largest market for Smartphone in the world by 2016. With the help of Internet on mobile phones (Smartphone), online news can be read anytime and anywhere.

We can say despite the growth of Internet users in India displacement effect of online media is very low. In the Western world, newspaper circulation is drastically going down, many news organisations have stopped printing the newspapers, and they only provide the news on their websites. But in India print media has maintained its place. They have started their on-line portals or websites that provide news as well.

Young generation is among the first to adopt new technologies, similarly in the media, they are keen to read news from online newspapers. As per this study 21 percent younger (15-20 age group) generation has reduced the use of traditional media (newspapers), this gap will increase in coming years in India as younger generation is using Internet from early schooling. They want news on demand, for latest news most of the people heavily rely on search engines. Whereas print newspapers provide news on next day. This is a significant disadvantage of printed newspapers in relation to news sites with respect to the fact that these present yesterday's news and charge for it $[31,32]$.

The decline of younger reader interest on the printed newspaper in India is also a big threat to Indian media industry. As Internet (online newspapers) may have destroyed the western countries newspaper's. But in India the print media is in safe position, they have started crossmedia production of news in both print and digital format.

They should publish maximum news related to the youth, and writing style also be used as per the younger generation need. Reporter should make stories shorter and pay attention to what is hot on social media, according to the need of the day, they should generate the news content. 
Newspaper has faced similar threat when radio and television media was introduced, but despite the growth of TV and Radio media newspapers is still popular in India. Similarly online media has not much affected the print newspaper circulation. People are using online newspapers as complimentary to the newspapers. In India both the newspaper, online and print are growing. Whereas is Western world print media is dying and online is flourishing.

\section{References}

1. Franklin B (2008) The future of newspapers. Journalism Studies 9(5): 630-641.

2. Lazarsfeld P (1940) Radio and the printed page: Dell, Sloan, \& Pearce New York, USA.

3. Belson W (1961) Effects of television on the reading and buying of newspapers and magazines. Public Opinion Quarterly, 25: 366-38.

4. De Leon D, Holsanova J (1997) Revealing user behaviour on the worldwide web. Lund University Cognitive Studies, 60, Lund.

5. Carlson D (2001) The Online Timeline A capsule history of online news and information systems.

6. Garrison B (1996) Successful strategies for computer-assisted reporting. Mahwah, NJ: L. Erlbaum.

7. Flanagin A, Metzger M (2001) Internet use in the contemporary media environment. Human Communication Research, 27: 153-181.

8. Fox S, Rainie L, Larsen E, Horrigan J, Lenhart A (2001)Wired Seniors. The Pew Internet and American Life Project.

9. Nie NH, Erbring L (2000) Internet and Society: A Preliminary Report. Palo Alto, CA: Stanford Institute for the Quantitative Study of Society Press.

10. Nie N, Hillygus S, Erbring L (2002) Internet use, interpersonal relations and sociability: Findings from a detailed time diary study, The Internet in Everyday Life London: Blackwell Publishers 215-243.

11. Robinson J (2010) UK and US see heaviest newspaper circulation declines.

12. Himmelweit HT, Swift B (1976) Continuities and discontinuities in media usage and taste: A longitudinal study. J Soc Issues 32: 133-156.

13. Katz E, Gurevitch M, Haas H (1973) On the use of the mass media for important things. American Sociological Review 36: 164-181.

14. Rosengren KE, Palmgreen P, Wenner L (1985) Media gratification research: Current perspectives. Beverly Hills, CA: SAGE Publications.

15. Domingo, David H (2008) Weblogs and journalism: a typology to explore the blurring boundaries. Nordicom Review 29: 3-15.

16. Barthelemy S (2011) The Future of Print Media.
17. Vyas RS, Singh NP, Bhabhra S (2007) Media displacement effect: Investigating the impact of Internet on newspaper reading habits of consumers. Vision: The Journal of Business Perspective 11: 29-40.

18. Tewari P (2015) The Habits of Online Newspaper Readers in India. J Socialomics 4: 124.

19. Westlund O, Fardigh MA (2011) Displacing or complementing effects of news sites on newspapers, 1998-2009. Int j media mana 13: 177-194.

20. De Waal E, Schoenbach K (2010) News sites' position in the mediascape: Uses, evaluations and media displacement effects over time. New Media \& Society.

21. Wadbring I, Bergstrom A (2010) The contribution of free dailies and news on the Web: Implications of media structural changes for the Swedish newspaper readership market. Northern Lights, 8: 139-155.

22. Zickuhr K, Smith A (2012) Digital differences. Pew Internet and American Life Project.

23. Nossek H, Adoni H, Nimrod G (2015) Is Print Really Dying? The State of Print Media Use in Europe. International Journal of Communication 9: 365-385.

24. Online surveys in marketing research: Pros and cons. International Journal of Market Research Llieva J, Baron S, Healey NM (2002) 44: 361-367.

25. Bachmann D, Elfrink J (1996) Tracking the progress of e-mail versus snail-mail. Marketing Research 8:31-35.

26. Garton L, Haythornthwaite C, Wellman B (1999) Studying on-line social networks. Doing Internet Research: Critical Issues and Methods for Examining the Net Thousand Oaks, CA: Sage 75-105.

27. Taylor H (2000) Does Internet research work? Comparing electronic survey results with telephone survey. Int J market Res 42: 51-63.

28. Yun GW, Trumbo CW (2000) Comparative response to a survey executed by post, email, and web form. Journal of Computer-Mediated Communication 6 (1).

29. Andrews D, Nonnecke B, Preece J (2003) Electronic Survey Methodology: A Case Study in Reaching Hard-to-Involve Internet Users. International Journal of Human-Computer Interaction 185-210.

30. Stanton JM (1998) An empirical assessment of data collection using the Internet. Personnel Psychology 51(3): 709-725.

31. Witmer DF, Colman RW, Katzman SL (1999) From paper-and-pencil to screen-and-keyboard: Toward a methodology for survey research on the Internet. Doing Internet Research: Critical Issues and Methods for Examining the Net Thousand Oaks, CA: Sage 145-161.

32. Singer JB (2008) Five Ws and an H: Digital challenges in newspaper newsrooms and boardrooms. International Journal on Media Management 10: 122-129. 